\title{
6. Globalisation, New Labour Migration and Development in Fiji
}

\section{Manoranjan Mohanty}

\section{Introduction}

Globalisation and migration are the two predominant and intertwined phenomena in the world today. Human mobility has become an integral part of the global economy. Since the early 1990s, the world has been witnessing a rapid process of internationalisation of capital, technology and economic activities. Global corporate activities through multinational and transnational corporations have grown rapidly. Trade and financial liberalisation is increasingly pronounced. The growth of mass media along with the development in transport and communication technologies and the free flow of information are leading to a rapidly 'shrinking world'. It is now an interconnected 'one world', whose economies, societies and cultures are more closely intertwined in what is commonly referred to as a 'global village'.

There has been increasing interaction and integration of national economic systems through the growth in international trade, investment and capital flows. Societies, economies and polities are now more interconnected, interdependent and affected by global changes.

Globalisation is now characterised by shrinking space and time and by vanishing borders, and globalising processes are dismantling obstacles to movement. As a result, there has been an increasing flow of people, goods, services, ideas, technologies and information across international borders. In simple terms, globalisation is defined as a "process that widens the extent and form of cross-border transactions among peoples, assets, goods and services and that deepens the economic interdependence between and among globalising entities, which may be private or public institutions or governments' (Lubbers 2000). Globalisation is not new but the present era of globalisation is characterised by new markets (e.g., foreign exchanges operating 24 hours a day); by new tools (e.g., Internet links, cellular phones); by new actors (e.g., the WTO); and by new rules (e.g., multilateral agreements on trade).

Globalising processes have far-reaching social, demographic, economic, political and environmental consequences. For example, the growing demand for labour in the international market and advancing transport and communication technologies have resulted in mass movements of people across national borders. The impact of such globalisation is, however, uneven and varies from country to country. 
This chapter explores the interlinkages between globalisation, international migration and development. It examines the emerging trends and contributing factors for labour migration in Oceania with special reference to the Fiji Islands. It also explores the impact of globalising processes on labour migration, trends in the flow of remittances and the overall impact of migration on development in the Fiji Islands.

\section{Globalisation and transnational migration}

Contemporary international migration is a systemic element in the process of globalisation and globalising processes are likely to increase migration pressures. The international migration system is now more integrated and has become more transnational in nature than ever before. According to a study by the International Labour Organisation (ILO), globalisation is expected to intensify international migration in the 21 st century as 'the free flow of goods and capital worsens income inequalities and shakes up traditional [labour] markets' (Stalker 2000). The study says this is not because of 'a liberalisation of immigration controls but because of growing [labour] supply pressures, rising income inequalities within and across nations brought about by globalisation itself and the revolution in information and communication technologies' (Stalker 2000).

Globalisation as a social and economic process prompts a 'proliferation of cross-border flows and transnational social networks' (Castles 2001) that connects migrants across transnational space. In a rapidly globalised world, the patterns of migration and the migrants' social relationships are changing fast. The migrants move in what are called 'transnational social spaces', which are the preconditions for and also the products of globalising processes (Faist 2000).

Globalisation has provided migrants with powerful tools such as Internet communication, mobile phones and email for close interaction with their homelands. As a result, transnational global networks have been established which in turn prompt more cross-border migration. The process of globalisation makes cultural and social capital available to migrants. While cultural capital refers to knowledge of other societies as well as information about migration and job opportunities, social capital encompasses migration networks that help further movements. Within transnational social spaces, most migrants prefer to move to places where their own communities have already settled. As a result, a 'chain migratory system' is being established.

\section{Dimensions of international migration}

International migration is a dynamic and fast-growing phenomenon. It is increasing not only in scale and speed, but is characterised by wide diversities in terms of people and countries involved (Global Commission on International Migration 2005: 42). The volume of migrants has increased dramatically and is expected to continue to rise in the future. According to the report by the Global 
Commission on International Migration (2005: 83), the number of international migrants has increased from 82 million in 1970 to nearly 200 million in 2005 or more than double in a span of 35 years. Of all international migrants, almost half were women and migrant populations represented 3 per cent of the total world population, which is equivalent to the population of Brazil, the fifth-largest country in the world. Another emerging migratory trend due largely to the globalising process is that some traditional emigrant countries have become countries of immigrants (for example, Ireland), and, similarly, many immigrant countries now have large emigrant flows, e.g., Australia, New Zealand and the UK (International Organisation of Migration 2005).

The Global Commission on International Migration's report (2005: 83) said that the immigrants' share of the total population was highest in Australia (Oceania; 18.7 per cent) followed by North America (12.9 per cent), Western Europe (7.7 per cent), Africa (2 per cent), Asia (1.4 per cent) and Latin America (1.1 per cent). The report also said that major global markets for migrants were the USA (20 per cent) followed by the Russian Federation (13.3 per cent), Germany (7. 3 per cent), Ukraine (4 per cent) and India (3.6 per cent).

\section{International migration and development}

Labour migration is one of the key forces of socioeconomic development. Relationships between migration and development are complex and multidimensional. Migration of people endowed with high levels of 'human capital' is beneficial and it helps the economic growth and development of many countries in the developing world such as Bangladesh, China, India and the Philippines. The emigration in labour surplus in developing countries provides a 'safety valve' for unemployed youth and relieves pressure on the labour market. Migration is also seen as one of the major contributors to population changes, which have significant impact on the process of development.

Globalising processes have prompted a 'brain drain' through large-scale emigration and also a 'brain gain' through returned skilled migrants. Some Asian countries, such as China, India and the Philippines, for example, see a shift from 'brain drain' to 'brain gain' as a result of their proactive policies to attract back emigrants with acquired skills and education (International Organisation of Migration 2005: 19). Hugo et al. (2001: 9) also found that countries such as China, India and Korea were witnessing 'hyper mobility involving remigration and return'. The outflow of human capital resources is seen to be beneficial to some developing countries due to the foreign exchange earnings generated through remittances. In many developing countries, remittances constitute a more important source of income than the Official Development Assistance (ODA) and Foreign Direct Investment (FDI) (Global Commission on International Migration 2005: 85). 
Globally, the formal transfers of remittances were about \$A202 billion in 2004 and another \$A404 billion were transferred informally (Global Commission on International Migration 2005: 85). Remitters use informal channels because they are cheaper and better suited to transferring funds to remote areas where formal channels do not operate (Ratha 2004). The formal transfers of remittances almost tripled the value of ODA and were the second largest source of external funding for developing countries after FDI (Global Commission on International Migration 2005: 85). According to the report of the Global Commission on International Migration, the three leading remittance-receiving countries in 2004 were Mexico (\$A21.5 billion a year), India (\$A13.4 billion) and the Philippines (\$A12 billion).

Remittances, Internet communication and access to travel, together with the support of migrant communities within the diaspora and hometown associations all provide the conditions for the transnational migrants to reside abroad and maintain ties with their country of origin, and are creating powerful tools for development (International Organisation of Migration 2005: 15). The role of remittances in economic growth and development is debatable, but many agree that remittances can help alleviate poverty and play a critical role in economic growth and development.

\section{Migration trends in Oceania}

Migration in Oceania is significant, with almost six million international migrants in the region in 2000. It shows the highest percentage per regional population globally and one of the highest rates of migration, growing at a rate of 2.1 per cent annually (International Organisation of Migration 2005). As seen elsewhere, there are more female than male international migrants in the Oceania region (Global Commission on International Migration 2005: 83).

The immigrant countries of Oceania, such as Australia and New Zealand, have experienced large emigrant flows in recent years. For example, during 2002-03, 50,463 people left Australia permanently, with most going to the UK, the USA and Asia. Similarly, New Zealand had a permanent emigration of 62,300 people during 2003-04 (International Organisation of Migration 2005: 130). Australasia (Australia and New Zealand), however, remains one of the major labour markets in Oceania, attracting more skilled immigrants worldwide including from Fiji and the other Pacific Island countries. In 2000, there were 5.8 million migrants in Australia alone (Global Commission on International Migration 2005).

Many small island countries in the Pacific region, such as Tonga and Samoa, have gained from the outflow of human capital resources largely to the Pacific Rim metropolitan countries, through the generation of foreign exchange from remittances sent by emigrants. According to Small and Dixon (2004), in the case of Tonga, 'it is migration, along with remittances of cash and goods from [those] who live and work overseas, that keeps the Tongan economy afloat'. Remittances 
are its major source of foreign exchange, accounting for about 50 per cent of GDP in 2002. About 75 per cent of all Tongan households reported receiving remittances from overseas and in some villages, remittances accounted for as much as 50 per cent of all household income. The inflow has helped in economic growth and development in the Pacific MIRAB economies (Bertram and Watters 1985).

\section{The changing nature of labour migration in Fiji}

Fiji is no exception. Globalisation has impacted on Fiji's labour migration directly and indirectly. Fiji has become a country of origin, transit and destination for migrants. In order to understand thoroughly the influences of globalising processes on labour migration in the Fiji Islands, an analysis of outward and inward movements of people is essential. There have been changing trends in labour migration in Fiji as a result of global changes and changing political, economic and developmental priorities in Fiji. Broadly, labour migration in the Fiji Islands can be identified in three phases as: mass immigration (1879-1919 and 1920-36); permanent labour migration (1970 onwards); temporary labour migration and contemporary immigration (since the early 1990s).

\section{Mass immigration phase (1879-1920 and 1920-36)}

As a product of the British indentured labour system, Indian immigrants, called 'girmitiyas', came to Fiji in 1879 to work in sugarcane plantations. Indians succeeded Melanesians as plantation labourers (Connell 1985: 45). Between 1879 and 1916, 60,000 Indian migrants arrived in Fiji and their work helped create the foundations of Fiji's sugar-based economy (Lal 2003). The system of indentured labour ended officially on January 1, 1920. By that time, there was a sizeable free Indian population in Fiji and they were mostly farmers from Punjab, and traders and merchants from Gujarat (Lal 2003). The Gujarati population in Fiji increased from 324 in 1921 to 2,500 by 1936 (Ali and Crocombe 1981). Their arrival prompted the rapid growth of trade and business in the Fiji Islands. The majority of Asians, particularly the Chinese, immigrated to Pacific countries and to Fiji under two systems. Some came under an indentured labour system and others as 'free emigrants' on a credit system (Willson, Moore and Munro 1990: 80). The first Chinese settlement was recorded in Levuka, the old capital of Fiji, in the 1870s, its occupants being gold miners from Australia who came to Fiji when the Australian mines were depleted (Yee 1974: 300).

\section{Permanent labour migration phase (since 1970)}

A process of permanent emigration started during and after independence in 1970 and it has been a continuing process since then. Fiji witnessed 'great waves' of outflow of skilled human resources during the 1980s and 1990s and again after May 2000 (Mohanty 2001, 2002). The total official outflow from Fiji was 
more than 91,000 between 1987 and 2004 (Table 1). Unofficial independent sources, however, estimate the figure to be more than 100,000 (Bedford 1989). Between 2000 and 2004, 27,000 citizens emigrated from Fiji. The permanent emigration process is dominated by the Indo-Fijians (88-9 per cent). The annual average rate of migration showed a varied pattern over the years. Before the 1987 coups, the annual average migration rate was 2,300 migrants a year, which increased to 4,900 during 1987-99, and to 5,800 migrants a year during 2000-03 (Mohanty 2001). Fiji has lost more than 3,800 professionals, technical and related workers since the coup in 2000 (Table 1). This represents more than half of Fiji's stock of middle- to high-level workers (Government of Fiji 2002: 41). Teachers are the single most dominant professional group that Fiji has been losing.

Table 1: Emigration of Fijian citizens by ethnic group and professional workers, 1987-2004

\begin{tabular}{|c|c|c|c|c|c|c|c|}
\hline \multirow[t]{2}{*}{ Year } & \multirow[t]{2}{*}{ Fijians } & \multirow[t]{2}{*}{ Indo-Fijians } & \multirow[t]{2}{*}{ Others } & \multirow[t]{2}{*}{ Total } & \multirow{2}{*}{$\begin{array}{c}\text { Annual } \\
\text { average } \\
\text { emigration } \\
\text { rate }\end{array}$} & \multicolumn{2}{|c|}{ Professionals** } \\
\hline & & & & & & Total & $\begin{array}{l}\text { Annual } \\
\text { average }\end{array}$ \\
\hline 1987-99 & 3,926 & 57,159 & 3,124 & 64,209 & 4,939 & 6,869 & 528 \\
\hline 2000-04* & 2,373 & 23,585 & 1,126 & 27,084 & 5,413 & 3,826 & 765 \\
\hline 1987-2004* & 6,299 & 80,744 & 4,250 & 91,293 & 5,070 & 10,695 & 594 \\
\hline
\end{tabular}

${ }^{*}$ The figure for 2004 is from January to September.

${ }^{* *}$ Includes professional, technical and related workers.

Source: Fiji Bureau of Statistics, 1987-2004, Tourism and Migration Statistics and Statistical News.

New Zealand, Australia, the USA and Canada are the four major traditional destination countries of Fiji's migrants. In 1980, about two-thirds of Fiji's emigrants entered Canada and the USA and another 29 per cent went to Australasia (Mohanty 2001: 63). Since 1987, this trend has been reversed. This reversal is attributed to many factors, such as geographic proximity, skilled labour demand, family reunion and the changing immigration policies of the receiving countries.

Push and pull factors are at work in the international migration process in Fiji. While factors such as land insecurities, unemployment (5-7 per cent during 1980-2001) and political upheavals were the main contributing push factors for emigration, the higher pay and standard of living, better economic opportunities, better health facilities and educational prospects for children in the metropolitan countries are some of the pull factors that greatly influenced migration decisions. The Reserve Bank of Fiji Quarterly Review said, '[I]t is quite clear that the political instability generated by [the] events of 1987 and 2000 gave greater impetus to the emigration process' (Government of Fiji 2002b: 40). Fiji lost more through the outflow of human capital resources than it gained through remittances. According to one estimate, the country lost directly and indirectly about \$F45 million annually through its human capital loss (Reddy, Mohanty and Naidu 
2004). Forsyth (1991: 37-44) in his study also found that there were large net negative flows of remittances in 1990.

\section{Temporary labour migration phase (since the early 1990s)}

From the 1970s to the 1990s, Fiji remained a labour emigrant country in Oceania. Partly under the influences of globalising processes, there has been a shift in trends in international migration in Fiji in the recent period. In addition to the continuing permanent Indo-Fijian emigration from the country, Fiji has been witnessing new trends in temporary migration, mostly indigenous Fijians, including peacekeeping forces, security personnel, nurses, sportspeople and students. Most of the indigenous Fijian migrants are moving to non-traditional areas such as the Middle East. For example, 'more than 1,000 former Fiji military and police officers are employed in Iraq' (Fiji Times 2005b). Under the influence of globalising processes, geographic proximity is no longer the primary driver of Fiji's current international migration. The Indo-Fijian and Fijian transmigrant populations created over the years maintain close ties with the homeland and remain actively involved in the social, cultural, economic and political life of Fiji. As Lal (2003: 5) says, '[A]lthough they live abroad, they maintain active contact with Fiji through a variety of means: the internet, telephone, video, periodic re-visits and remitting money and goods to Fiji.' The transnational overseas social networks also prompt more migration from Fiji.

\section{Fiji's international peacekeeping}

One of the major trends in recent years is the intensification of the temporary movement of peacekeeping forces from Fiji to distant parts of the world. Fiji gives high priority to participation in the UN's international peacekeeping processes, which dates from the late 1970s with the dispatch of the first troops to Lebanon in 1978 under the UN Interim Force in Lebanon (UNIFIL), and intensified in the 1990s. Fiji's international peacekeeping forces have been posted to global flashpoints under various missions, mostly under the UN but sometimes not, as in the case of the Sinai, Bougainville and Solomon Islands. Apart from joining the British Army, Fiji's soldiers have been playing a prominent role in international peace and security and in the process of nation-building in conflict-laden countries such as Afghanistan, Angola, PNG (Bougainville), Croatia, East Timor, Iraq, Kosovo, Kuwait, Lebanon, Namibia, Zimbabwe, Rwanda, Egypt (the Sinai), Solomon Islands, Somalia and, recently, Sudan. In addition, the number of Fijians working for private security companies as guards, escorts and other security personnel, especially in the Middle East, is significant. The movement of peacekeeping forces and security personnel overseas has generated substantial personal remittances (Table 2). 
Student mobility is another type of temporary migration from Fiji. There have been an increasing number of students on overseas scholarship programs. The number of overseas scholarships awarded to students from Fiji was more than 530 during 1991-2000 (Fiji Public Service Commission 2002). In addition, Indo-Fijian cultural and social associations overseas are sponsoring Indo-Fijian students from Fiji (Lal 2003: 5).

Nurses from Fiji have been migrating to other Pacific countries and the UK. Rokoduru (2002) in her research finds that nurses have been migrating from Fiji to the Marshall Islands since 1995. She found 11 nurses from Fiji (29 per cent of the total) were working in Ebeye's Health Centre in 2002 and they were predominantly single males. A step-wise migration process is also at work as more than half of the Fijian nurses wanted to migrate to the USA after a stay of five years in the Marshall Islands.

A notable trend in Fiji's migratory stream is that the proportion of Indo-Fijian emigrants has been declining and, in contrast, the proportion of indigenous Fijians has been on the rise. The proportion of indigenous Fijian migrants to total emigration has doubled from 5 per cent in 1991 to 10 per cent in 2003 (Fiji Bureau of Statistics 1991-2003). Correspondingly, the proportion of Indo-Fijian emigrants has declined from 90 per cent to 86 per cent during the same period. This changing trend might be attributed more to the impact of globalising processes and to exogenous factors rather than endogenous ones. Although the number of indigenous Fijians in the total emigration stream remains relatively small, the progressive increase in proportion of indigenous Fijian emigration and skilled categories is of great concern. As Robertson (2005) says, the 'recent desire by as many as 15,000 mainly Fijians to work in West Asia has generated domestic racial fears'.

There are marked differences between the 'old' and 'new' contemporary labour migratory trends in Fiji. While the former was predominantly a permanent and partly involuntary type consisting largely of Indo-Fijians, and attributed primarily to endogenous factors, the latter is a temporary, voluntary type consisting of indigenous Fijians under internal as well as external or global influences. Another difference is that while the former stream was towards traditional areas such as Australia, Canada, New Zealand and the USA, the latter is towards new areas, especially the Middle East and Pacific countries. Moreover, while the former type of migration contributed insignificantly to the generation of remittances, the new migration is primarily a remittance-generating and development-driven process.

\section{Contemporary immigration}

Large-scale skilled emigration from Fiji has been accompanied by increased immigration in recent decades. In 2000, Asian immigrants accounted for about 
half of the total immigrants in Fiji. Chinese immigrants are the oldest and the largest Asian migrant groups in Fiji. They accounted for a little less than one-third of the total immigrants to Fiji and slightly less than two-thirds of the transnational Asian immigrants in the country in 2000 (Government of Fiji 2001). Other immigrants to Fiji came from Australia (16 per cent), the EU (9 per cent), New Zealand ( 9 per cent), the USA ( 6 per cent), the UK ( 4 per cent) and the Pacific Islands (4 per cent).

\section{Remittances in Fiji}

Fiji, traditionally a non-remittance country, is now becoming a remittance economy with thousands of citizens heading to work overseas. The country has joined other Pacific remittance economies such as Samoa and Tonga.

Until the late 1990s, the volume of remittances in Fiji due to the old (permanent) migration was insignificant. For example, it was only about \$F36 million in 1993, mainly in the form of gifts and maintenances. Since the late 1990s, Fiji has been generating remittances mainly through personal receipts from new labour migrants, especially peacekeeping forces. Personal remittances accounted for about 97 per cent of the total remittances to the country in 2004. Personal remittances involve three categories of receipts: gifts and maintenance received by individuals, funds brought into the country by the immigrants, including legacies, and salaries and allowances of expatriates and pensions for retirees. While personal receipts through salary and allowances constituted little more than two-thirds of the total remittances, receipts in the form of gifts and maintenance received by individuals accounted for a little less than one-third in 2004 (Reserve Bank of Fiji 2005). The remittances through immigrant transfers constituted insignificant proportions of the total personal remittances $(0.3$ per cent).

The volume of remittances in Fiji has increased since 2000. Between 1993 and 1999, the growth of remittances was slow, only 38 per cent with an average figure of \$F49 million a year. It increased more than 218 per cent during 2000-04, with an average amount of \$F205 million a year (Table 2). The flow of total personal remittances accounted for more than $\$ F 1$ billion during the period 2000-04. This dramatic rise was due mainly to the remittances generated through the salaries and allowances of peacekeeping forces and private security personnel abroad. 
Table 2: Trends in personal remittances in Fiji, 1993-2004

\begin{tabular}{|c|c|c|c|}
\hline Period & $\begin{array}{c}\text { Total personal remittances } \\
\text { (\$F million) }\end{array}$ & $\begin{array}{c}\text { Annual average rate (\$F } \\
\text { million) }\end{array}$ & Change \% \\
\hline $\mathbf{1 9 9 3 - 9 9}$ & 344.32 & 49.2 & +38.4 \\
\hline $\mathbf{2 0 0 0 - 0 4}$ & $1,023.50$ & 204.7 & +218.3 \\
\hline $\mathbf{1 9 9 3 - 2 0 0 4}$ & $1,367.82$ & 114.0 & 726.2 \\
\hline
\end{tabular}

Source: Reserve Bank of Fiji, 2005.

The volume of formally transferred remittances has increased from about \$F36 million in 1993 to \$F297 million in 2004, a growth of more than 720 per cent between 1993 and 2004 (Table 2). Beside the formal transfer, a substantial volume of personal remittances is transferred to Fiji informally and remains officially unrecorded (Fiji Times 2005a). The total volume of remittances from formal and informal transfers to Fiji can be estimated at \$F450-500 million. This accounts for about 7 per cent of the GDP of the country.

As Table 3 shows, the income generated through personal remittances in Fiji is now next to the foreign exchange earnings through tourism. In 2004, personal remittances were worth more than earnings from garments, textiles and footwear and were also worth more than sugar, gold, fish and mineral water export earnings combined (Table 3).

Table 3: Sectoral foreign exchange earnings and remittances in Fiji, 1999-2004

\begin{tabular}{|c|c|c|c|}
\hline Item & $\begin{array}{c}\text { Foreign exchange earnings } \\
\text { (\$F million) } \\
1999\end{array}$ & $\begin{array}{c}\text { Foreign exchange earnings } \\
\text { (\$F million) } \\
2004\end{array}$ & Growth \% 1999-2004 \\
\hline Tourism & 559.0 & 727.0 & +30.0 \\
\hline $\begin{array}{c}\text { Garments, textiles and } \\
\text { footwear }\end{array}$ & 365.9 & 291.0 & -20.5 \\
\hline Sugar and molasses & 275.6 & 188.4 & +31.6 \\
\hline Gold & 76.4 & 88.5 & +47.8 \\
\hline Fish & 57.5 & 85.0 & +798.3 \\
\hline Mineral water & 5.9 & 53.0 & +497.2 \\
\hline Personalremittances & 49.8 & 297.4 & \\
\hline
\end{tabular}

Source: Government of Fiji, Reserve Bank of Fiji and Trade Release, 2005.

\section{Migration and development in Fiji}

Labour migration helps economic growth and development in many countries of the world. The migration-development relationships are, however, critical in small Pacific Island states such as Fiji, where a limited human resource stock exists and the demand for skilled human resources exceeds supply. While the outflow of skilled migrants is seen as conducive to the development of the larger countries of Asia, in smaller states such as Fiji it is regarded mostly as detrimental to sustainable development.

Migration and development relationships can be understood through labour demand and supply relations, demographic changes and remittance-development 
linkages. The large-scale emigration from Fiji is not only changing Fiji's population dynamics, it is influencing its political dynamics. Permanent emigration from Fiji has created serious shortages of skilled manpower in the economy. There are 'some critical areas, such as the medical profession, teaching and other specialized services, where labour shortages were most acute and still exist today' (Government of Fiji 2002: 42). This has greatly impacted on productivity, thus jeopardising the long-term development process. Due to skilled emigration, the quality of services and the overall human development of the country have been affected to a large extent. This is evidenced in the current UNDP Human Development Report (2005), which shows that Fiji's Human Development Index rank fell to 92 in 2005 from its previous rank of 66 in 2000. Yet migration also has positive impacts on development, for example, expanding export opportunities for local businesses and increasing traffic for the national airlines. Emigration in Fiji is also seen as a 'safety valve' in a situation when the supply of formal jobs has fallen short of the demand of fresh entrants to the labour force.

The growing remittances generated through temporary labour migration from Fiji in recent years might play a significant role in the context of low foreign investment and declining sugar and garment export earnings. Whether remittances are used for 'consumption or buying houses, or for other investments, they stimulate demand for goods and services in the economy' and 'enable a country to pay for imports, repay foreign debt and improve creditworthiness' (International Organisation of Migration 2005: 269). They also help alleviate poverty. As studies show, personal remittances derived through nurses' migration from Fiji, for example, have helped family members 'to pay for general family subsistence, for the welfare of their children and ... other traditional obligations in Fiji' (Rokoduru 2002).

\section{Conclusion}

Fiji is at the crossroads. International labour migration from Fiji has always been of concern primarily because of the drain of human and financial capital from the country. The draining of labour and financial capital from its system might inhibit economic growth and jeopardise the process of development. A small island developing state such as Fiji, with its limited human resource stock, cannot afford to lose human capital, the basic foundation for achieving sustainable development; however, the international migration trends, especially for Indo-Fijians, are likely to change in the future.

In the quest for alternative development strategies in the wake of declines in the sugar and garment sectors, the new trends of Fijian labour migration to distant locations might be seen as a viable development option provided the remittances are invested productively. The temporary new migration might also counter the loss of financial capital incurred through skilled emigration. 
Migration, development and international relations are closely linked. With the signing of diplomatic ties and the growth of good bilateral relations with countries such as China, India, Japan and Kuwait in recent times, there exists a potential for improvement in trade and investment in Fiji. Positive international ties and globalising processes might accelerate new labour mobility in Fiji and a consequent growth of remittances and economic growth in the future.

\section{References}

Ali, A. and R. Crocombe. 1981. Pacific Indians. Suva: Institute of Pacific Studies, University of the South Pacific.

Bedford, R. D. 1989. 'Out of Fiji ... A perspective on migration after the coups.' Pacific Viewpoint, 30 (2). pp. 142-53.

Beine, M. et al. 1999. Brain Drain and Economic Growth: Theory and Evidence. University de Versailles, http://www.cybercable.tm.fr/-jarmah/public_html/HRRapoportl1.htm

Bertram, I. G. and R. F. Watters. 1985. 'The MIRAB economy in South Pacific microstates.' Pacific Viewpoint, 26. pp. 498-519.

Castles, S. 2001. 'Migration and community formation under conditions of globalization.' Paper presented at conference on Reinventing Society in the New Economy, March 9-10, University of Toronto, Canada.

Connell, J. 1985. 'Migration, Employment and Development in the South Pacific.' Country Report, No. 4. Noumea: South Pacific Commission.

Faist, T. 2000. 'Transnationalisation in international migration; implications for the study of citizenship and culture.' Ethnic and Racial Studies, 23 (2). pp. 189-222.

Fiji Bureau of Statistics. 1987-2004. Tourism and Migration Statistics and Statistical News. Suva: Fiji Bureau of Statistics.

Fiji Times. 2005a. 'State to study second largest foreign exchange earner.' November 11. p. 8.

Fiji Times. 2005b. 'Fijians sing carols in Iraq.' December 22. p. 10.

Fiji Public Service Commission. 1991-95. Annual Reports. Suva: Fiji Public Service Commission.

Fiji Public Service Commission. 2002. Fiji Government Scholarship Awards. Public Service Commission, http://www.fijichris.gov.fj/

Forsyth, D. J. C. 1991. Migration and Remittance in the South Pacific Forum Island Countries. Unpublished report prepared for the South Pacific Forum Secretariat, Suva, Fiji. 
Global Commission on International Migration. 2005. Migration in an interconnected World: New directions for action. A report of the Global Commission on International Migration, Geneva, Switzerland, October.

Government of Fiji, Fiji Islands Bureau of Statistics. 1998. Fiji 1996 Census of Population and Housing: General Tables. Suva: Fiji Islands Bureau of Statistics.

Government of Fiji. 2002a. Annual Reports - 2000 and 2001. Suva: Immigration Department.

Government of Fiji. 2002b. 'Impact of brain drain in Fiji.' RBF Quarterly Review (December). pp. 40-5.

Hugo, G. with D. Rudd and K. Harris. 2001. 'Emigration from Australia: Economic implications.' Committee for the Economic Development of Australia Information Paper, No. 77, June.

International Organisation of Migration. 2005. World Migration Report: Costs and Benefits of International Migration, Vol. 3. Geneva, Switzerland.

Lal, B. V. 2003. Fiji Islands: From immigration to emigration. Canberra: The Australian National University. http://www.migrationinformation.org/profiles/display.cfm? $\mathrm{ID}=110$

Lubbers, R. 2000. Trends in economic and social globalisation: Challenges and obstacles. Cambridge, Mass.: Harvard University. http://globalize.kub.nl/

Mohanty, M. 2001. 'Contemporary emigration from Fiji: Some trends and issues in the post-Independence era.' In V. Naidu, E. Vasta and C. Hawksley (eds), Current Trends in South Pacific Migration, Working Paper No. 7, APMRN Secretariat, University of Wollongong. pp. 54-73.

Mohanty, M. 2002. 'Human capital resource outflow and development in Fiji islands.' InS. M. Lee and S. Chongsithiphol (eds), E-Globalisation in the Pacific Age, Proceedings of Pan-Pacific Conference XIX, May 29-31, 2002, Bangkok. pp. 363-5.

Ratha, D. 2004. Understanding the importance of remittances. Washington: Migration Policy Institute, World Bank. http://www.migrationinformation.org/Feature/display.cfm?ID $=256$

Reddy, M., M. Mohanty and V. Naidu. 2004. 'Economic cost of human capital loss from Fiji: Implications for sustainable development.' International Migration Review, 38 (4). pp. 1447-62.

Reserve Bank of Fiji. 2005. 'Statistics on personal remittances.' Personal communication, Economics Department, Reserve Bank of Fiji, Suva, Fiji.

Robertson, R. 2005. 'From multiculturalism to trans-culturalism: Moving beyond post colonialism in Fiji.' Paper presented at a seminar in the Pacific 
Globalisation and Governance in the Pacific Islands

Institute of Advanced Studies in Development and Governance, University of the South Pacific, Suva, Fiji.

Rokoduru, A. 2002. 'The contemporary migration of skilled labour from Fiji to Pacific Island countries (PICS).' In R. Bedford (ed.), 5th International APMRN Conference, Fiji 2002: Selected Papers, Working Paper No. 12, APMRN Secretariat, University of Wollongong. pp. 43-8.

Small, C. A. and D. L. Dixon. 2004. Tonga: Migration and the homeland. February. http://www.migration.org/feature/print.cfm?ID $=198$

Stalker, P. 2000. Workers Without Frontiers - The Impact of Globalisation on International Migration. Geneva: ILO.

Taylor, J. E. 1999. 'The new economics of labour migration and the role of remittances in migration process.' Journal of International Migration, 37 (1). pp. 63-88.

UNDP. 2005. Human Development Report. New York: Oxford University Press.

Willson, M., C. Moore and D. Munro. 1990. 'Asian workers in the Pacific.' In C. Moore, J. Leckie and D. Munro (eds), Labour in the South Pacific, Townsville: James Cook University.

Yee, S. J. 1974. The Chinese in the Pacific. Suva, Fiji: theSouth Pacific Social Sciences in association with the UNDP. 